\title{
EKSISTENSI DAN PROBLEMATIKA PROFESI NOTARIS
}

\author{
Oleh : H. Enju Juanda, S.H., M.H.")
}

\begin{abstract}
ABSTRAK
Untuk mewujudkan Negara Republik Indonesia sebagai Negara Hukum yang berdasarkan Pancasila dan Undang-undang Dasar Negara Republik Indonesia Tahun 1945 guna menjamin kepastian, ketertiban dan perlindungan hukum bagi yang membutuhkan alat bukti tertulis yang bersifat otentik yang didalamnya menerangkan mengenai keadaan, peristiwa atau perbuatan hukum diperlukan Jabatan Notaris maka pada Tahun 2004 dikeluarkan Undang-undang Republik Indonesia Nomor : 30 Tahun 2004 tentang Jabatan Notaris sebagaimana telah dirubah dengan Nomor Undang-Undang Republik Indonesia Nomor 2 Tahun 2014 Tentang Perubahan Atas Undang-Undang Republik Indonesia Nomor 30 Tahun 2004 Tentang Jabatan Notaris.

Berdasarkan Ketentuan Pasal 1 angka 1 Undang-undang Republik Indonesia Nomor : 30 Tahun 2004 tentang Jabatan Notaris sebagaimana telah dirubah dengan Undang-Undang Republik Indonesia Nomor 2 Tahun 2014 Tentang Perubahan Atas Undang-Undang Nomor 30 Tahun 2004 Tentang Jabatan Notaris memberikan definisi Notaris yaitu sebagai berikut : Notaris adalah pejabat umum yang berwenang untuk membuat akta otentik dan kewenangan lainnya sebagaimana dimaksud dalam Undang-undang ini.

Sehingga dengan demikian oleh karena Akta Notaris adalah merupakan Akta Otentik, maka Akta Notaris mempunyai kekuatan pembuktian sempurna atau lengkap, sebagaimana ditentukan Pasal 165 HIR.

Kata Kunci : Akta Notaris Merupakan Akta Otentik Yang Berkekuatan Pembuktian Sempurna Atau Lengkap.
\end{abstract}

\section{ABSTRACT}

To realize the Republic of Indonesia as a state law based on Pancasila and the Constitution of the Republic of Indonesia Year 1945 in order to ensure certainty, order and legal protection for those who require written evidence to be authentic in it explain the situation, event or legal act required Position notary then in 2004 issued the Law of the Republic of Indonesia Number 30 Year 2004 concerning Notary as amended by No. 2 Year 2014 concerning the Amendment to Law Number 30 Year 2004 on Notary.

Under the provisions of Article 1 paragraph 1 of Law of the Republic of Indonesia Number 30 Year 2004 concerning Notary as amended by No. 2 Year 2014 concerning the Amendment to Law Number 30 Year 2004 on Notary provides definitions Notary as follows: Notary is an official public authorities to create an authentic deed and other authorities referred to in this Act.

Thus because of Deed is an authentic deed, the deed of Notary has the strength of evidence is perfect or complete, as provided in Article $165 \mathrm{HIR}$.

Keywords: authentic Letter of Deed Is Its Strength of Evidence Perfect or Complete.

*) Dosen Tetap Fakultas Hukum Universitas Galuh. 


\section{PENDAHULUAN}

Notaris berasal dari perkataan Notarius ialah nama yang pada zaman Romawi diberikan kepada orang-orang yang menjalankan pekerjaan penulis. Ada juga pendapat yang mengatakan bahwa nama Notaris berasal dari "Nota Literia" yaitu tanda (letter merk atau karakter) yang mengatakan sesuatu perkataan. Kemudian dalam abad ke lima dan ke enam sebutan Notarius (notarii) diberikan kepada penulis (sekretaris) pribadi Raja (kaizer), sedangkan pada akhir abad kelima sebutan tersebut diberikan kepada pegawai-pegawai istana yang melaksanakan pekerjaan administratif (Soegondo Notodisoerjo; 1993 : 13).

Keberadaan Jabatan Notaris di Indonesia pertama kali tercatat pada tanggal 27 Agustus 1620 dengan diangkatnya Melchior Kerchem dari Belanda menjadi Notaris yang disebut Notarium Publicium di Jakarta, pada saat itu masih bernama Jacatra tugasnya adalah untuk kepentingan publik khususnya menjalankan kegiatannya sebagai Pejabat Umum yang melayani masyarakat. (Komar Andasasmita; 1991 : 29).

Perkembangan selanjutnya mengenai eksistensi Notaris dapat dijelaskan bahwa tahun 1949 diadakan Konferensi Meja Bundar (KMB) di Den
Haag, Nederland, tanggal 23 Agustus22 September 1949. Salah satu dari KMB tersebut yaitu, adanya Penyerahan Kedaulatan dari Pemerintahan Belanda kepada Republik Indonesia Serikat untuk seluruh Wilayah Indonesia kecuali Irian Barat yang sekarang adalah Papua. Adanya Penyerahan Kedaulatan tersebut membawa akibat kepada status Notaris berkewarganegaraan Belanda di Indonesia harus meninggalkan jabatannya. Dengan demikian, terjadilah kekosongan Notaris di Indonesia, untuk mengisi kekosongan tersebut, sesuai dengan kewenangan yang ada pada Menteri Kehakiman Republik Indonesia Serikat dari tahun 1949 sampai dengan tahun 1954 menetapkan dan mengangkat Wakil Notaris untuk menjalankan tugas Jabatan Notaris dan menerima protokol yang berasal dari Notaris yang berkewarganegaraan Belanda. Tahun 1954, Pemerintah Republik Indonesia mengeluarkan Undang-undang Nomor 33 Tahun 1954 tentang Wakil Notaris dan Wakil Notaris Sementara. Pada saat itu, yang disebut sebagai Notaris adalah mereka yang diangkat berdasarkan Ketentuan Pasal 2 Ayat (1) Stbl. 1860:3. jo Pasal 1 huruf a Undang-undang Nomor 33 Tahun 1954. Berdasarkan Undang-undang Nomor 33 Tahun 1954 ini juga sekaligus ditegaskan berlakunya Reglement op 
Het Notaris Abmt in Nederlands Indie (Stbl.1860:3) sebagai Reglemen tentang Jabatan Notaris di Indonesia yang lebih dikenal dengan Peraturan Jabatan Notaris (PJN) untuk Notaris di Indonesia (Pengurus Pusat INI; 2008 : 104).

Selanjutnya untuk mewujudkan Negara Republik Indonesia sebagai Negara Hukum yang berdasarkan Pancasila dan Undang-undang Dasar Negara Republik Indonesia Tahun 1945 guna menjamin kepastian, ketertiban dan perlindungan hukum bagi yang membutuhkan alat bukti tertulis yang bersifat otentik yang didalamnya menerangkan mengenai keadaan, peristiwa atau perbuatan hukum diperlukan Jabatan Notaris maka pada Tahun 2004 dikeluarkan Undangundang Republik Indonesia Nomor : 30 Tahun 2004 tentang Jabatan Notaris sebagaimana telah dirubah dengan Undang-Udnang Nomor 2 Tahun 2014 Tentang Perubahan Atas UndangUndang Nomor 30 Tahun 2004 Tentang Jabatan Notaris.

\section{Tugas, Kewenangan dan Kewajiban Notaris}

Berdasarkan Ketentuan Pasal 1 angka 1 Undang-undang Republik Indonesia Nomor : 30 Tahun 2004 tentang Jabatan Notaris sebagaimana telah dirubah dengan Nomor 2 Tahun
2014 Tentang Perubahan Atas UndangUndang Nomor 30 Tahun 2004 Tentang Jabatan Notaris memberikan definisi Notaris yaitu sebagai berikut :

Notaris adalah pejabat umum yang berwenang untuk membuat akta otentik dan kewenangan lainnya sebagaimana dimaksud dalam Undang-undang ini.

Tugas Notaris adalah mengkonstatir hubungan hukum antara para pihak dalam bentuk tertulis dalam format tertentu, sehingga merupakan suatu akta otentik. la adalah pembuat dokumen yang kuat dalam suatu proses hukum (Tan Thong Kie; 2000 : 159)

Sikap Notaris pada saat melaksanakan profesinya secara prinsip Notaris bersikap pasif melayani para pihak yang menghadap kepadanya. Notaris hanya bertugas mencatat atau menuliskan dalam akta apa-apa yang diterangkan para pihak, tidak berhak mengubah atau menambah apa yang diterangkan para penghadap (R. Subekti; 1987 : 27).

Notaris merupakan suatu profesi yang mempunyai karakteristik tersendiri dibandingkan profesi lain seperti Advokat, Jaksa, Arbiter dan Hakim, mengingat fungsi dan kedudukan Notaris yang sangat menentukan, maka dalam melakukan tugas profesionalnya seorang notaris harus mempunyai 
integritas moral. Adapun yang dimaksud dengan moral adalah segala penilaian, ukuran, karakter, perilaku, kesadaran, yang berhubungan dengan apa-apa yang baik dan apa-apa yang buruk, atau mana yang benar dan mana yang salah berdasarkan prinsip-prinsip umum yang diberlakukan berdasarkan atas kesadaran manusia, yang berasal perasaan dan perhitungan probabilitas bukan berdasarkan pembuktian ilmiah (Munir Fuady, 2012 : 70), sehingga karenanya dalam menjalankan tugas dan kewenangannya seorang Notaris sangat penting untuk memegang teguh nilai-nilai moral tersebut dan tentu saja norma-norma yang berlaku di masyarakat.

Adapun yang menjadi kewenangan Notaris adalah sebagaimana yang ditetapkan dalam Pasal 15 Undang-undang Republik Indonesia Nomor 30 Tahun 2004 tentang Jabatan Notaris sebagaimana telah dirubah dengan Undang-Undang Republik Indonesia Nomor 2 Tahun 2014 Tentang Perubahan Atas UndangUndang Nomor 30 Tahun 2004 Tentang Jabatan Notaris yang menentukan sebagai berikut :

(1) Notaris berwenang membuat akta otentik mengenai semua perbuatan, perjanjian, dan ketetapan yang diharuskan oleh peraturan perundang-undangan dan/atau yang dikehendaki oleh yang berkepentingan untuk dinyatakan dalam akta otentik, menjamin kepastian tanggal pembuatan akta, menyimpan akta, memberikan grosse, salinan dan kutipan akta, semuanya itu sepanjang pembuatan akta-akta itu tidak juga ditugaskan atau dikecualikan kepada pejabat lain atau orang lain yang ditetapkan oleh undang-undang.

(2) Selain kewenangan sebagaimana dimaksud pada ayat (1), Notaris berwenang pula: :

a. mengesahkan tanda tangan dan menetapkan kepastian tanggal surat di bawah tangan dengan mendaftar dalam buku khusus;

b. membukukan surat-surat di bawah tangan dengan mendaftar dalam buku khusus;

c. membuat kopi dari asli surat-surat di bawah tangan berupa salinan yang memuat uraian sebagaimana ditulis dan digambarkan dalam surat yang bersangkutan;

d. melakukan pengesahan kecocokan fotokopi dengan surat aslinya;

e. memberikan penyuluhan hukum sehubungan dengan pembuatan akta; 
f. membuat akta yang berkaitan dengan pertanahan; atau

g. membuat akta risalah lelang.

(3) Selain kewenangan sebagaimana dimaksud pada ayat (1) dan ayat (2), Notaris mempunyai kewenangan lain yang diatur dalam peraturan perundang-undangan.

Sedangkan yang menjadi kewajiban Notaris adalah sebagaimana ditetapkan Pasal 16 Ayat (1) Undangundang Republik Indonesia Nomor 30 Tahun 2004 tentang Jabatan Notaris sebagaimana telah dirubah dengan Undang-Undang Republik Indonesia Nomor 2 Tahun 2014 Tentang Perubahan Atas Undang-Undang Nomor 30 Tahun 2004 Tentang Jabatan Notaris sebagaimana yang menentukan sebagai berikut :

a. bertindak amanah, jujur, saksama, mandiri, tidak berpihak, dan menjaga kepentingan pihak yang terkait dalam perbuatan hukum;

b. membuat Akta dalam bentuk Minuta Akta dan menyimpannya sebagai bagian dari Protokol Notaris;

c. melekatkan surat dan dokumen serta sidik jari penghadap pada Minuta Akta;

d. mengeluarkan Grosse Akta, Salinan Akta, atau Kutipan Akta berdasarkan Minuta Akta; e. memberikan pelayanan sesuai dengan ketentuan dalam UndangUndang ini, kecuali ada alasan untuk menolaknya;

f. merahasiakan segala sesuatu mengenai Akta yang dibuatnya dan segala keterangan yang diperoleh guna pembuatan Akta sesuai dengan sumpah/janji jabatan, kecuali undang-undang menentukan lain;

g. menjilid Akta yang dibuatnya dalam 1 (satu) bulan menjadi buku yang memuat tidak lebih dari 50 (lima puluh) Akta, dan jika jumlah Akta tidak dapat dimuat dalam satu buku, Akta tersebut dapat dijilid menjadi lebih dari satu buku, dan mencatat jumlah Minuta Akta, bulan, dan tahun pembuatannya pada sampul setiap buku;

h. membuat daftar dari Akta protes terhadap tidak dibayar atau tidak diterimanya surat berharga;

i. membuat daftar Akta yang berkenaan dengan wasiat menurut urutan waktu pembuatan Akta setiap bulan;

j. mengirimkan daftar Akta sebagaimana dimaksud dalam huruf i atau daftar nihil yang berkenaan dengan wasiat ke pusat daftar wasiat pada kementerian yang menyelenggarakan urusan pemerintahan di bidang hukum 
dalam waktu 5 (lima) hari pada minggu pertama setiap bulan berikutnya;

k. mencatat dalam repertorium tanggal pengiriman daftar wasiat pada setiap akhir bulan;

I. mempunyai cap atau stempel yang memuat lambang negara Republik Indonesia dan pada ruang yang melingkarinya dituliskan nama, jabatan, dan tempat kedudukan yang bersangkutan;

m. membacakan Akta di hadapan penghadap dengan dihadiri oleh paling sedikit 2 (dua) orang saksi, atau 4 (empat) orang saksi khusus untuk pembuatan Akta wasiat di bawah tangan, dan ditandatangani pada

\section{Kekuatan Pembuktian Akta Notaris}

Pada perkembangan dewasa ini masyarakat dalam melakukan perbuatan hukum dalam hubungan hukum antara satu dengan lainnya terutama dalam hubungan keperdataan menghendaki perbuatan hukum tersebut dituangkan dalam sebuah Akta.

Akta adalah surat yang diberi tanda tangan, yang memuat peristiwaperistiwa yang menjadi dasar dari pada suatu hak atau perikatan yang dibuat sejak semula dengan sengaja untuk pembuktian (Sudikno Mertokusumo; 2001 : 101) Akta dalam Pengetahuan IImu Hukum dikenal dua macam yaitu Akta di bawah tangan dan Akta Otentik.

Yang dimaksud dengan Akta Otentik Pasal 1868 Kitab Undangundang Hukum Perdata menyatakan sebagai berikut :

Suatu akta otentik ialah suatu akta yang didalam bentuk yang ditentukan oleh undangundang,dibuat oleh atau di hadapan pegawai-pegawai umum yang berkuasa untuk itu di tempat di mana akta dibuatnya.

Akta Otentik itu mengandung beberapa unsur pokok yaitu akta yang dibuat oleh dan atau dihadapan pejabat umum yang ditentukan Undang-undang yang dimaksudkan dengan pejabat umum adalah Notaris, Hakim, Panitera, Juru Sita, Pegawai Pencatat Sipil, yang berarti bahwa surat-surat yang dibuat oleh dan atau dihadapan pejabat tersebut seperti akta notaris, vonis, surat berita acara sidang, proses perihal pensitaan, surat perkawinan, kelahiran, kematian adalah merupakan akta otentik (Teguh Samudra; 1992 : 41).

Sehingga dengan demikian oleh karena Akta Notaris adalah merupakan Akta Otentik, maka Akta Notaris mempunyai kekuatan pembuktian sempurna atau lengkap, sebagaimana 
ditentukan Pasal 165 HIR Akta Otentik berkekuatan pembuktian sempurna dapat kita lihat dalam ketentuan Pasa Pasal 165 HIR menentukan sebagai berikut :

\begin{abstract}
"Akta otentik yaitu suatu surat yang diperbuat oleh atau dihadapan pegawai umum yang berkuasa akan membuatnya, mewujudkan bukti yang cukup bagi kedua belah dan ahli warisnya serta sekalian orang yang mendapat hak daripadanya yaitu tentang segala hal, yang tersebut di dalam surat itu dan juga tentang yang tercantum dalam surat itu sebagai pemerbitahuan saja, tetapi yang tersebut kemudian itu hanya sekedar diberitahukan itu langsung berhubungan dengan pokok dalam akta itu." (Mr. R. Tresna : 1993 : 142).
\end{abstract}

\section{Potensi Tindak Pidana Yang Disangkakan Terhadap Notaris}

Ketentuan Undang-undang

Republik Indonesia Nomor 30 Tahun 2004 tentang Jabatan Notaris sebagaimana telah dirubah dengan Undang-Undang Republik Indonesia Nomor 2 Tahun 2014 Tentang Perubahan Atas Undang-Undang Nomor 30 Tahun 2004 Tentang Jabatan Notaris tidak mengatur secara limatatif sanksi pidana bagi Notaris dalam melaksanakan jabatannya, akan tetapi meskipun Undang-undang tersebut tidak memuat ketentuan Pidana bagi Notaris tidak berarti seorang Notaris dalam menjalankan profesinya tidak dapat dijerat hukum melainkan Ketentuan Hukum Pidana tetap melekat kepadanya.

Adapun ketentuan pidana yang sangat mungkin disangkakan terhadap seorang Notaris dalam menjalankan jabatannya terutama dalam pembuatan Akta Otentik adalah sebagai berikut :

1. Ketentuan Pasal 263 Kitab Undangundang Hukum Pidana yang berbunyi sebagai berikut :

(1) Barangsiapa membuat surat palsu atau memalsukan surat, yang dapat menerbitkan sesuatu hak, sesuatu perjanjian (kewajiban) atau sesuatu pembebasan utang, atau yang boleh dipergunakan sebagai keterangan bagi sesuatu perbuatan, dengan maksud akan menggunakan atau menyuruh orang lain menggunakan suratsurat itu seolah-olah surat itu asli dan tidak dipalsukan, maka kalau mempergunakannya dapat mendatangkan sesuatu kerugian dihukum karena pemalsuan surat, dengan hukuman penjara selama-lamanya enam tahun.

(2) Dengan hukuman serupa itu juga dihukum, barangsiapa dengan sengaja menggunakan surat palsu atau yang dipalsukan itu 
seolah-olah surat asli dan tidak dipalsukan, kalau hal mempergunakan dapat mendatangkan sesuatu kerugian. (KUHP 35, 52, 64-2, 276, 277, $416,417,486)$.

2. Pasal 264 Kitab Undang-undang Hukum Pidana yang berbunyi sebagai berikut :

(1) Sitersalah dalam perkara memalsukan surat, dihukum penjara selama-lamanya delapan tahun, kalau perbuatan itu dilakukan :

1e. mengenai surat authentiek (KUHP 266).

2e. mengenai surat utang atau surat tanda utang (certificaat) dari sesuatu surat negara atau sebagainya atau dari sesuatu balai (instelling) umum;

3e. mengenai saham-saham (aandeel) atau surat utang atau certificaat, tanda saham atau tanda utang dari sesuatu perserikatan, balai, atau perseroan atau maskapai;

4e. mengenai talon atau surat tanda untung sero (dividend) atau tanda bunga uang dari salah satu surat yang diterangkan pada $2 \mathrm{e}$ dan $3 \mathrm{e}$, atau tentang surat keterangan yang dikeluarkan akan pengganti surat itu;

5e. mengenai surat utangpiutang atau surat perniagaan yang akan diedarkan.

(2) Dengan hukuman serupa itu juga dihukum, barangsiapa dengan sengaja menggunakan akte itu seolah-olah isinya cocok dengan hal yang sebenarnya, ayat pertama, seolah-olah itu surat asli dan tidak dipalsukan, jika pemakaian surat itu dapat mendatangkan sesuatu kerugian. (KUHP 4-3e, 35, 52, 64-2, 165, 266, 275 s, 277 s, 416 s, 486).

3. Pasal 372 Kitab Undang-undang Hukum Pidana yang berbunyi sebagai berikut :

Barangsiapa dengan sengaja memiliki dengan melawan hak sesuatu barang yang sama sekali atau sebagiannya termasuk kepunyaan orang lain dan barang itu ada dalam tangannya bukan karena kejahatan, dihukum karena penggelapan, dengan hukuman penjara selama-lamanya empat tahun atau denda sebanyak- 
banyaknya Rp. 900,- (KUHP 35, 43, 373, $376 \mathrm{~s}, 486$ ).

4. Pasal 374 Kitab Undang-undang Hukum Pidana yang berbunyi sebagai berikut :

Penggelapan yang dilakukan oleh orang yang memegang barang itu berhubung dengan pekerjaannya atau jabatannya atau karena ia mendapat upah uang, dihukum penjara selama-lamanya lima tahun. (KUHP 35, 43, 376 s, 415, 432, 486, 513).

5. Pencucian uang (Undang-undang Republik Indonesia Nomor 8 Tahun 2010 tentang Pencegahan dan Pemberantasan Tindak Pidana Pencucian Uang). Modusnya, pemilik uang melakukan pembelian saham yang kemudian dicatat dalam akta notaris. Modus pembelian saham memudahkan pelaku pencucian uang untuk memindahkan uang. Jika berbentuk saham, otomatis uang hasil kejahatan menjadi sah, sehingga mudah dipindahkan sesuai keinginan pelaku tindak pidana. Karenanya, notaris sebagai profesi bertugas membuat akta pendirian perusahaan dan jual beli saham diminta mewaspadai kemungkinan terjadinya pencucian uang.

Ketentuan-ketentuan Pasal-pasal tersebut di atas dapat disangkakan terhadap seorang Notaris dalam melakukan Jabatannya dengan sangkaan seorang Notaris dianggap orang yang turut serta melakukan (medepleger) karena dianggap bersama-sama melakukan hal itu sebagaimana ditetapkan Pasal 55 dan Pasal 56 Kitab Undang-undang Hukum Pidana.

\section{Problematika Profesi Jabatan Notaris}

Kekuatan pembuktian sempurna atau lengkap sebuah Akta Notaris berlaku terhadap para pihak yang termuat dalam Akta Otentik tersebut, hal itu kiranya dapat diilustrasikan ke dalam sebuah contoh sebagai berikut :

Si $A$ meminjam uang kepada $B$, pada waktu $A$ meminjam uang kepada $B$ tersebut perjanjiannya dilakukan dihadapan seorang Notaris yang menuangkannya ke dalam suatu akta. Apabila dikemudian hari Si B mengelak dan tidak mengakui meminjam uang kepada $A$, maka apabila dalam proses persidangan diajukan alat bukti tertulis akta notaris yang berisi $B$ telah meminjam uang kepada $A$ maka hakim terikat kepada apa yang termuat dalam Akta Notaris tersebut artinya hakim akan 
menjatuhkan putusan

mempunyai utang kepada $\mathrm{B}$.

Akan tetapi ada kemungkinan pihak yang dikalahkan dengan bukti Akta Notaris tersebut merasa tidak puas dan menyalahkan Notaris dengan membuat berbagai alasan misalnya dia tidak pernah bertemu dengan notaris, atau dia mengatakan tidak mendapatkan penjelasan dari notaris atau dia mengatakan pada waktu membuat akta tersebut berpura-pura dan alasanalasan lainnya yang pada pokoknya menyudutkan notaris dalam melaksanakan jabatannya seakan-akan terbitnya akta tersebut karena terdapat kesalahan dari pihak Notaris.

Untuk menghadapi kemungkinan persoalan-persoalan tersebut kiranya seorang Notaris dalam melaksanakan pekerjaannya harus selalu memperhatikan tugas, wewenang dan tanggungjawabnya dengan dilandasi moralitas yang tinggi serta ada hal-hal yang perlu dijalankan antara lain :

- Membuat pernyataan dari para pihak yang membuat Akta dengan tulisan langsung sendiri yang pada pokoknya yang bersangkutan benarbenar telah membuat Akta tersebut.

- Disediakan sarana Visual misalnya Foto atau CCTV.

- Saksi diusahakan bukan karyawan Notaris yang bersangkutan.

\section{Penutup}

Kiranya Eksistensi Notaris sangat diperlukan oleh masyarakat, akan tetapi Notaris juga dalam melaksanakan jabatannya harus bertindak dibarengi moralitas dan memegang teguh peraturan perundang-undangan yang berlaku.

\section{DAFTAR PUSTAKA}

\section{Literatur :}

Andasasmita Komar; Notaris I, Ikatan Notaris Jawa Barat, Bandung, 1991.

Fuady Munir, Hukum Kontrak (Dari Sudut Pandang Hukum Bisnis), PT Citra Aditya Bhakti, Bandung, 1999.

Subekti R; Hukum Pembuktian, Pradnya Paramita, Jakarta, 1987.

Subekti R dan R. Tjitro Sudibyo, Kitab Undang-undang Hukum Perdata, Pradnya Paramita, Jakarta, 1992.

Soesilo R, Kitab Undang-undang Hukum Pidana (KUHP serta Komentarkomentarnya Lengkap Pasal Demi Pasal, Politea Bogor, 1995.

Tresna R, HIR dan Komentarnya. Pradja Paramita, Jakarta, 2000.

Mertokusumo Sudikno, Hukum Acara Perdata Indonesia, Liberty, Yogyakarta, 1990. 
Notodisoerjo Soegondo; Hukum Notariat Di Indonesia, PT Raja Grafindo Persada, Jakarta, 1993.

Thong Kie Tan; Studi Notariat, Serba Serbi Praktek Notaris Buku I, PT. Ichtiar Baru, Jakarta, 2000.

Samudra Teguh, Hukum Pembuktian Dalam Acara Perdata, Alumni, Bandung, 1992.

\section{Sumber Perundang-undangan :}

Undang-Undang Dasar Negara Republik Indonesia Tahun 1945.

Undang-undang Republik Indonesia Nomor 30 Tahun 2004 tentang Jabatan Notaris sebagaimana telah dirubah dengan Nomor 2 Tahun 2014 Tentang Perubahan Atas Undang-Undang Nomor 30 Tahun 2004 Tentang Jabatan Notaris. 